\title{
The Effect of Electrode Immersion Time and Ageing on N719 Dye-Sensitized Solar Cells Performance
}

\author{
Ewelina Krawczak ${ }^{*}$, Agata Zdyb \\ 1 Faculty of Environmental Engineering, Lublin University of Technology, Nadbystrzycka 38, 20-618 Lublin, \\ Poland \\ *Corresponding autor's e-mail: e.krawczak@pollub.pl
}

\begin{abstract}
One of the most promising devices belonging to the third generation of photovoltaic technologies is dye-sensitized solar cell (DSSC). It can be considered as an economic substitute for the first and second generation of solar cells which provides relatively high conversion efficiency at low cost of material and simple manufacturing. This technology is widely developed nowadays thus it can contribute the meeting of the current and future energy demands. However, much work should be done to increase solar-electricity conversion efficiency of DSSC. It is identified that a crucial component which strongly affects the performance of the working dye-sensitized cell is dye sensitizer used to enhance the light harvesting. The adjustment of the amount of the adsorbed dye by a modification of photoelectrode immersion time in dye solution plays a crucial role. The objective of this study was to report the influence of electrode immersion time on dye-sensitized solar cells performance and to evaluate the stability of obtained cells. DSSC assemblies were prepared in the sandwich way with the working area equal to $0.8 \mathrm{~cm}^{2}$. The impact of various immersion times in $\mathrm{N} 719$ dye solution of the $\mathrm{TiO}_{2}$ covered photoelectrodes have been investigated. In the study, the process of encapsulation of the cells with sealant gaskets was enhanced which caused the improvement of the stability and tightness of the obtained DSSC devices. The methodological process adopted in this investigation includes measurements of current-voltage $(I-V)$ characteristics performed right after cell preparation, and after 72 hours to evaluate the role of ageing. The characterization of the obtained solar cells was carried out under standard test conditions (STC; temperature $25^{\circ} \mathrm{C}$, irradiance $100 \mathrm{~mW} / \mathrm{cm}^{2}$, air mass AM 1.5). On the basis of $I-V$ curves measurements, characteristic operating parameters of the obtained DSSC assemblies such as open circuit voltage $\left(V_{O C}\right)$, short circuit current $\left(I_{S C}\right)$, and maximum power point (MPP) have been established. The results of this research indicate that the time of electrode immersion in the dye solution affects strongly the DSSC performance. Thus, the control of the stage of the dye adsorption by the $\mathrm{TiO}_{2}$ layer is vitally important.
\end{abstract}

Keywords: photovoltaic, PV, dye sensitized solar cells, DSSC, dyes, N719

\section{INTRODUCTION}

Continuous development in each field of industry all over the world and thus growing energy demand have a detrimental effect on natural habitat. According to [bp-stats-review-2019-fullreport.pdf], in 2019 the strongest growth in energy power demand was noticed in 20 -year period time, which was equal to $3.7 \%$. The main resources, which are still used for electricity production, are fossil fuels, such as coal, natural gas, or oil. It is claimed that the energy acquisition process is the main cause of environmental pollution [Louwen et al., 2016]. The fossil fuels combustion causes emission of greenhouse gases, especially $\mathrm{CO}_{2}$, and thus the climate change. The main problem which communities have to tackle is how to preserve the environment during the energy production process and reduce the level of greenhouse gas emissions into the atmosphere [Höök and Tang, 2013]. It should be mentioned that carbon dioxide emissions increased by $2.0 \%$ in 2019 [bp-stats-review-2019-full-report.pdf]. What is more, the Earth's resources are finite and becoming scarcer every day. This is the result of overusing natural resources regardless of lack of 
the supplies replenishment possibilities [bp-statsreview-2019-full-report.pdf]. Therefore, preserving vital resources is a high priority these days and the productive solution for energy production is strongly needed. The exploration of alternative energy sources is crucial and for that reason, the researchers' attention is focused on this area. In 2019, the renewable power installed all over the World noticed increment by $14.5 \%$ which is closed to record increase in 2017 [bp-stats-review-2019-full-report.pdf].

Among all renewables, the Sun is regarded as the most meaningful energy source with huge potential. The above-mentioned factors caused a researchers' big interest in the photovoltaic $(P V)$ area. Such an advanced development in photovoltaics is noticed not only in the investigations of single solar cells but also plants [Gulkowski et al., 2019; Zidane et al., 2019] and installations of photovoltaic roof tiles [Kurz and Nawrowski, 2017; Wajs et al., 2020].

Nowadays, three main photovoltaic generations can be distinguished in the PV market, whether the first two, based on silicon and thin films, are the most popular ones. Dye-sensitized solar cells are great representatives of photovoltaic devices, which belong to the third generation of photovoltaic solar cells. They are considered as low-cost technology which can be a promising replacement for the commonly used first generation of solar cells [O'Regan and Grätzel, 1991]. Grätzel and G24 Power team obtained the highest efficiency of dye-sensitized solar cells equal to 14.1\% [https://www.nrel.gov]. Significant work has been done in DSSC area since 1991, when the outbreak of DSSC was noticed. However, there are still further challenges for researchers: to improve device efficiency, as well as durability and stability because these issues have not been comprehensively studied yet.

Dye-sensitized solar cell is usually composed of: a) working electrode, also called photoanode, modified by photosensitizing; b) counter electrode which is covered with a catalyst, usually platinum; c) liquid state electrolyte with a redox couple $\left(\mathrm{I}^{-} / \mathrm{I}_{3}^{-}\right)$. The mesoporous photoanode is a key component that normally consists of transparent conductive oxide (TCO) layer partly covered with nanocrystalline titanium dioxide $\left(\mathrm{TiO}_{2}\right)$ thin layer. The $\mathrm{TiO}_{2}$ is used in DSSC because of high possibility of the dye adsorption and appropriate energy level [Quintana et al., 2007]. TCO glass substrate is usually made of indium-doped tin oxide (ITO) [Shikoh et al., 2017; Hossain et al., 2018] or fluorine-doped tin oxide (FTO) [Subalakshmi and Senthilselvan, 2018]. However, nowadays the FTO glasses are more common to use due to their higher temperature resistance in comparison with ITO. As the temperature rises, the electrical properties of ITO become deteriorated. Among different oxide-based materials, $\mathrm{ZnO}$ enriched with trivalent dopants, such as $\mathrm{Al}$ [Zdyb et al., 2018;2016], Ga [Gong et al., 2014; Parthiban et al., 2015] and B [Zhang et al., 2016; Ueno et al., 2013] is the valuable replacement to ITO and FTO since it is able to offer wide band gap, good optical (high visible transmittance) and electrical properties (low resistivity) simultaneously. The efficiency of dye-sensitized solar cell highly depends on the quality of the photoanode due to determination of electron transfer, capability of light harvesting, optimal cooperation between TCO glass and electrolyte [Kundu et al., 2017; Galliano et al., 2018; J. Gong et al., 2017]. The counter electrode (CE) is also based on ITO or FTO transparent conductive oxides-covered glass substrates. The main role of counter electrode is dye regeneration by catalyzation of reduction of $\mathrm{I}_{3}^{-}$to $\mathrm{I}^{-}$ions and collecting the electrons from the external circuit [Grätzel, 2005]. The liquid state electrolyte with a redox couple $\left(\mathrm{I}^{-} / \mathrm{I}_{3}{ }^{-}\right)$ is commonly used due to assurance of high electron transfer and large recombination resistance [Teuscher et al., 2014]. The role which photosensitizer plays in dye-sensitized solar cell assembly is also very important. Photosensitizer should be characterized by a wide absorption spectrum (from the visible to near infrared region) that extend the absorption spectrum of $\mathrm{TiO}_{2}$ layer, and provide efficient electron injection into the working electrode. When incident light reach the dyesensitized solar cells surface, the electrons of the sensitizer adsorbed onto surface of $\mathrm{TiO}_{2}$ become exited and then they are transferred into the conduction band of $\mathrm{TiO}_{2}$ [Krawczyk et al., 2018]. The electrons are infused into the conductive layer of the transparent oxide material, ITO or FTO, and then they reach the counter electrode through the external circuit. To complete the working cycle, the oxidized dye is regenerated by the electrolyte with electrons that are collected at counter electrode. In order to regenerate the electrolyte, the reduction reaction occurs at counter electrode which leads to restoring the initial state [Nazeeruddin et al., 2011]. Taking into account all the factors mentioned above, in order to improve the 
power conversion efficiency (PCE) of dye-sensitized solar cells, the research is conducted in the field of photoelectrodes [Unal et al., 2020; Peng and $\mathrm{Xu}, 2020$ ], electrolytes [Önen et al., 2019; Chowdhury et al., 2020], counter electrodes [Rahman et al., 2019; Zalas and Jelak, 2020] and photosensitizers. The photosenitizers can be divided into two main groups: metal-free dyes and metal complex dyes, based mainly on ruthenium [Karim et al., 2019]. Nowadays, the natural dyes, such as pigments extracted from flowers, leaves, and fruits of some plants, are under strong development [Kabir et al., 2019; Krawczak and Zdyb, 2019; Singh and Koiry, 2018; Zdyb and Krawczyk, 2016], but still the DSSC based on ruthenium complexes are characterized by the highest working parameters. Many photosensitizers based on $\mathrm{Ru}$ element were developed, such as N3 ("red" dye), N749 ("black" dye), and N719. However, there are still issues, such as stability, tightness, and influence the immersion time on PCE, which must be improved.

In this work, N719 dye was applied in DSSC as a sensitizer and a relation was established between the concentration of the dye, the time of electrode dipping in the dye solution, and DSSC performance. The effect of ageing of the cells was also studied in terms of its influence on the DSSC working parameters. The performed series of experiments allowed evaluating of sealing procedure that was worked out in order to obtain durable cell structure.

\section{METHODOLOGY}

\section{Preparation of $\mathrm{TiO}_{2}$ photoanode}

The $\mathrm{TiO}_{2}$ paste was prepared following the procedure described in [Ito et al., 2007]. Mesoporous $\mathrm{TiO}_{2}$ layers were prepared by the use of $\mathrm{TiO}_{2}$ paste onto fluorine-doped tin oxide-covered glasses substrates. The FTO glasses with a size of $2 \times 2.5 \mathrm{~cm}$, which were purchased from Gratecell Solar, are characterized by $18 \Omega /$ sq sheet resistance. Prior to the deposition process, the substrates were chemically cleaned in acetone and ethanol, and dried in nitrogen gas flow. Thin $\mathrm{TiO}_{2}$ layers were formed firstly by the use of doctor blade technique in the rectangular shape of $0.8 \mathrm{~cm}^{2}$ area $(\boldsymbol{A})$ and then the spin-coating. Following the paste deposition process, the layers were sintered in the temperature up to $450^{\circ}$ in a few-steps process in order to obtain layers crystallization and enhance particles interconnectivity. The sintering process was carried out in the programmable high-temperature titan hotplate from Greatcell company with a possibility to control the ramp times, constant times, and temperature. The samples were cooled down naturally and then were moved directly to N719 dye solution.

\section{Assembling of dye-sensitized solar cells}

The dye-sensitized solar cells were prepared based on different concentrations of the dye and various immersion times of photoanodes. The N719 dye solutions were prepared with the use of $99.8 \%$ ethanol and N719 (Di-tetrabutylammonium cis-bis(isothiocyanato)bis(2,2'-bipyridyl-4,4'dicarboxylato)ruthenium(II)) dye from SigmaAldrich. Dye solutions were ultrasonically mixed for 10 minutes in order to improve the solubility of dye particles. The following concentrations of dye in absolute ethanol were prepared: $0.25 \mathrm{mM}$, $0.5 \mathrm{mM}$, and $1 \mathrm{mM}$. Prepared $\mathrm{TiO}_{2}$ photoanodes were immersed in the N719 dye solutions and remained there for 1 hour, 2 hours, or 24 hours in complete darkness. After the immersion process, the samples were rinsed with ethanol $(99.8 \%)$ to remove additional dye particles from $\mathrm{TiO}_{2}$ thin layers and dried at room temperature $\left(\mathrm{RT}=25^{\circ} \mathrm{C}\right)$. In order to assemble the solar cells, the prefabricated Pt-coated counter electrodes, purchased from Greatcell Solar, were used. Encapsulation of the cells was realised by using the low-temperature thermoplastic gasket sealant (from Dye Sol) with a $0.8 \mathrm{~cm}^{2}$ cut space by applying temperature and pressure. The solar cells were assembled in sandwich way then heated up to $125^{\circ}$ in order to encapsulate the whole structures properly and finally cooled down naturally. High performance EL- HPE electrolyte by Greatcell Solar was injected by the drilled hole in the back of counter electrode. In order to enhance charge collection, the contacts of silver paste were deposited. The steps required to assemble the dye-sensitized solar cells are presented in Figure 1.

\section{Characterization of dye-sensitized solar cells}

The current-voltage $(I-V)$ characteristics of the obtained dye-sensitized solar cells were measured by the use of SUN 3000 Abet Technolgies solar simulator with a xenon lamp. The investigation was carried out under the light intensity $(\boldsymbol{G})$ 


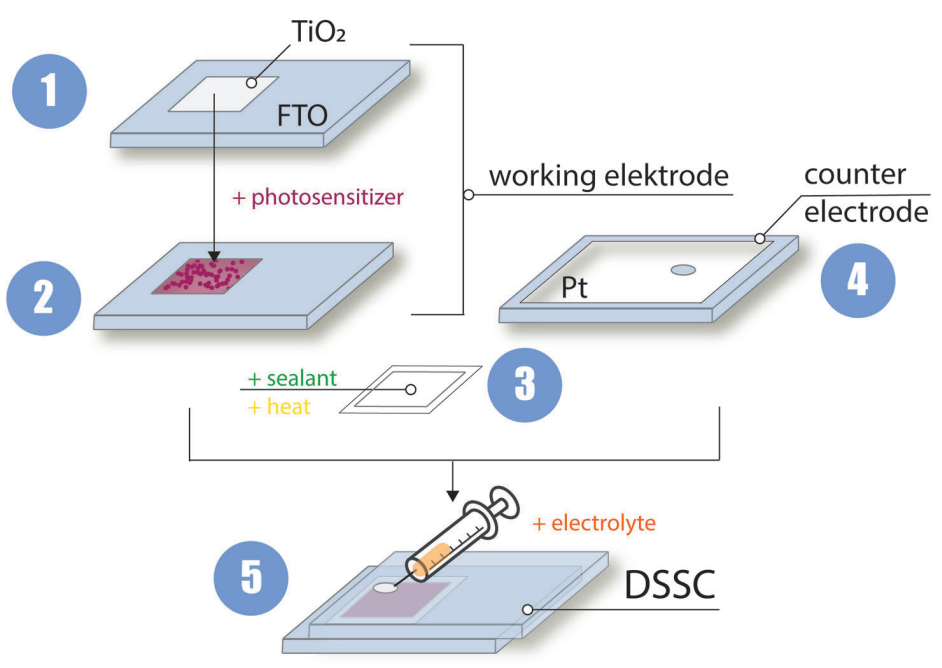

Figure 1. Assembling of dye-sensitized solar cells - scheme.

of $100 \mathrm{~mW} / \mathrm{cm}^{2}$ which was calibrated with the use of standard Si solar cells. Additional parameters were: temperature equal to $25^{\circ} \mathrm{C}$ and $\mathrm{AM} 1.5$. In order to measure the generated photocurrent, the Keithley Instruments, model 2440, digital source meter was used. The measurements were carried out directly after assembling DSSC device and 72 hours later in order to evaluate the ageing effect. The working parameters of the DSSC, such as $I_{s c}$-short circuit current, $V_{o c}$-open-circuit voltage, $I_{M P P}$ and $V_{M P}$ - maximum power point current and voltage respectively, $M P P$ - maximum power point, as well as the value of fill factor $(F F)$ and efficiency were calculated with the use of Matlab software. The efficiency of the achieved DSSCs was calculated on the basis of equation (1).

$$
\eta=\frac{P_{\max }}{P_{\text {in }}}=\frac{I_{\max } \cdot V_{\text {max }}}{P_{\text {in }}}=\frac{I_{s c} \cdot V_{o c} \cdot F F}{G * A}[-]
$$

where: $P_{\max }$ is maximum power output and $P_{\text {in }}$ is incoming light power. As can be seen from equation (1), the value of maximum power is defined as a product of the maximum current $\left(I_{\max }\right)$ and maximum voltage $\left(V_{\text {max }}\right)$ which can be obtained by the solar cell. Nonetheless, these two values are not generally used for the comparison of solar cells, because they are not directly visible in the $I-V$ curves. Fill factor $(F F)$ is determined by the relation between the maximum power $\left(P_{M P P}\right)$ that the cell can produce under given operating conditions, and the product of open-circuit voltage and short-circuit current, Eq (2). This factor indicates the quality of the solar cell, the closer it is to 1 , the more power it can provide.

$$
F F=\frac{P_{M P P}}{I_{S C} \cdot V_{o c}}[-]
$$

\section{RESULTS AND DISCUSSION}

Three sets of dye-sensitized solar cells were carefully made according to the precise description presented in the previous section. In order to find optimal technological parameters related to immersion time and the concentration of dye solution, a great number of experiments was conducted. Each measurement of $I-V$ characteristic was performed for freshly assembled cells and subsequently after $72 \mathrm{~h}$ (three days) to evaluate the stability of the cells and the changes in their electrical parameters The parameters of each experiment series are shown in Table 1.

Figures 2-4 present the exemplary characteristics of the cells that exhibit the best achieved photovoltaic parameters. Figure 2 depicts $I-V$ characteristics obtained for dye-sensitized solar

Table 1. Technological parameters of the tested dye cells.

\begin{tabular}{|c|c|c|c|}
\hline$N^{\circ}$ & \multirow{2}{*}{ Dye } & $\begin{array}{c}\text { Dye concentration } \\
(\mathrm{mM})\end{array}$ & $\begin{array}{c}\text { Dipping time } \\
(\mathrm{h})\end{array}$ \\
\hline \multirow{2nny}{*}{$\mathrm{N} 719$} & 0.25 & $1 \mathrm{~h}, 2 \mathrm{~h}, 24 \mathrm{~h}$ \\
\cline { 3 - 4 } 2 & \multirow{2}{*}{$\mathrm{N} 7 \mathrm{~h}, 2 \mathrm{~h}, 24 \mathrm{~h}$} \\
\cline { 3 - 4 } 3 & & 1.00 & $1 \mathrm{~h}, 2 \mathrm{~h}, 24 \mathrm{~h}$ \\
\hline
\end{tabular}


cells which were immersed for 24 hours in N719 dye solution with concertation of $0.25 \mathrm{mM}$, measured directly after DSSC preparation and 72 hours later.

As can be seen from Figure 2, at the outset, the value of the short-circuit current was $8.59 \mathrm{~mA}$, whereas the open circuit voltage was equal to $693.07 \mathrm{mV}$. The short circuit current density $I_{s c}$ value of the freshly made DSSC cell was equal to $10.74 \mathrm{~mA} / \mathrm{cm}^{2}, V_{M P P}$ and $I_{M P P}$ were $6.72 \mathrm{~mA}$ and $469.72 \mathrm{mV}$ respectively and thus the maximum power was $3.16 \mathrm{~mW}$. After 72 hours, the increase in all working parameters can be observed. Increase in $V_{o c}(712.54 \mathrm{mV}), I_{s c}\left(11.49 \mathrm{~mA} / \mathrm{cm}^{2}\right)$, $V_{M P P}(474.4 \mathrm{mV}), I_{M P P}(7.29 \mathrm{~mA})$ was noticed. What is more, the $10 \%$ change in $I_{s c}$ was distinguished (from 8.59 to $9.19 \mathrm{~mA}$ ). The efficiency of the DSSC changed from $3.94 \%$ to $4.33 \%$ and the increase in maximum power value to $3.46 \mathrm{~mW}$ was also observed. The value of the $F F$ did not change significantly, prior ageing it was $52.97 \%$, whereas at the end of the process it was equal to $52.85 \%$.

The dye-sensitized solar cells obtained by dipping the electrode in $0.5 \mathrm{mM} \mathrm{N719-dye} \mathrm{solu-}$ tion for 2 hours also showed an increase of the working parameters. The current-voltage curves are shown in Figure 3. It is interesting to notice that the samples obtained from these experiments were characterized by higher outset values than obtained by 24 hour-immersion but in $0.25 \mathrm{mM}$ dye solution (Figure 2). However, the smaller change is visible in measurements made directly after DSSC preparation and after 72 hours in comparison with the previous ones.

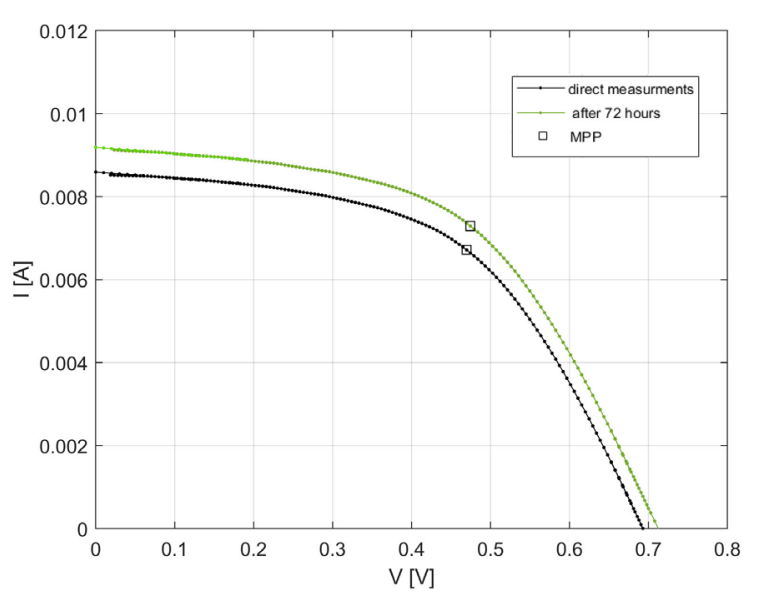

Figure 2. $I-V$ characteristics for N719 dye-based DSSC performed right after cell preparation, and after $72 \mathrm{~h}$, obtained for immersion time equal to $24 \mathrm{~h}$ and $0.25 \mathrm{mM}$ dye solution.
The $I_{s c}$ value changed from $9.76 \mathrm{~mA}$ to $9.97 \mathrm{~mA}$, which means $2 \%$ of the variation. Thus, the short-circuit current density also changed in the range of $12.21 \mathrm{~mA} / \mathrm{cm}^{2}-12.47 \mathrm{~mA} / \mathrm{cm}^{2}$. The $V_{o c}$ increased from $708.5 \mathrm{mV}$ to $723.98 \mathrm{mV}$ and so the values of $I_{M P P}$ (from 7.82 to $8.10 \mathrm{~mA}$ ), $V_{M P P}$ (from 465.00 to $479.11 \mathrm{mV}$ ). The $7 \%$ change was observed in maximum power point value which at the beginning was equal to $3.64 \mathrm{~mW}$ and after 72 hours was $3.88 \mathrm{~mW}$. The gentle variations were also noticed in $F F$ that changed from $52.58 \%$ to $53.78 \%$ and $\eta$ which was equal to $4.55 \%$ at the beginning and later to $4.85 \%$. All these measurements show the good stability of the obtained dye-sensitized solar cell.

In Figure 4, the $I-V$ characteristics are shown for the immersion in $1 \mathrm{mM}$ dye solution which took 1 hour time. In these experiments, the positive change also can be observed after 72 hours in the prepared dye-sensitized solar cells. Initially obtained values of the majority of the parameters were lower than after ageing process. The $V_{o c}$ value increased from $691.4 \mathrm{mV}$ to $713.31 \mathrm{mV}, I_{M P P}$ value changed from $7.37 \mathrm{~mA}$ to $7.49 \mathrm{~mA}$, as well as $V_{M P P}$ value rose from $455.59 \mathrm{mV}$ to $469.7 \mathrm{mV}$. Thus, the maximum power values noticed $5 \%$ increase, from $3.36 \mathrm{~mW}$ to $3.52 \mathrm{~mW}$, the $F F$ also changed from $49.15 \%$ to $50.16 \%$. What is more, the variation in the working parameters reflected in the variation of the $\eta$ in which $20 \%$ improvement was distinguished (4.19\% to $5.03 \%)$.

The working parameters of all prepared sets of dye-sensitized solar cells are summarized in Table 2 in which short circuit current density $\left(I_{s c}\right)$, open-circuit voltage $\left(V_{o c}\right)$, maximum power point

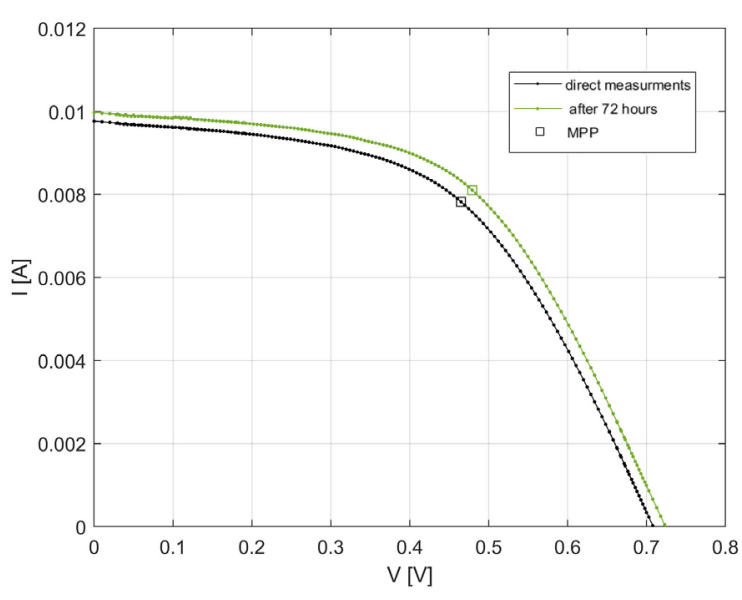

Figure 3. $I-V$ characteristics for N719 dye-based DSSC performed right after cell preparation, and after $72 \mathrm{~h}$, obtained for immersion time equal to $2 \mathrm{~h}$ and $0.5 \mathrm{mM}$ dye solution. 


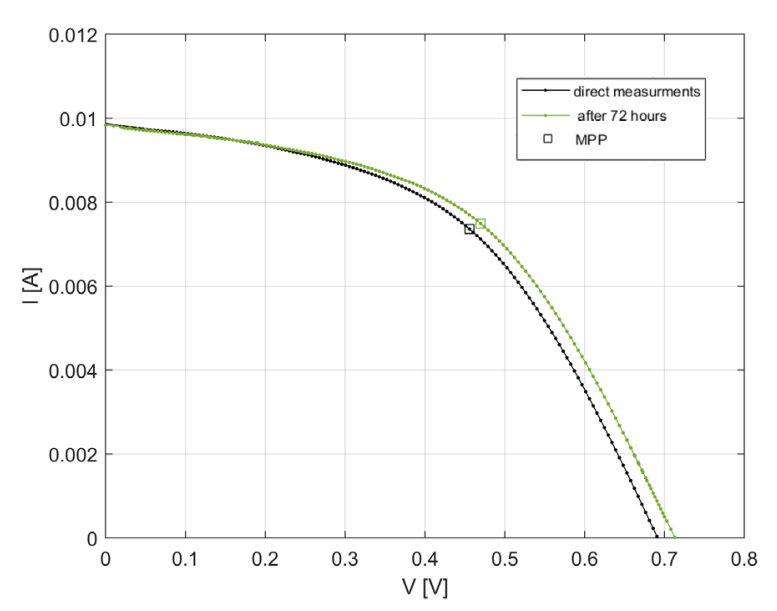

Figure 4. $I-V$ characteristics for N719 dye-based DSSC performed right after cell preparation, and after $72 \mathrm{~h}$, obtained for immersion time equal to $1 \mathrm{~h}$ and $1.0 \mathrm{mM}$ dye solution.

current $\left(I_{M P P}\right)$ maximum power point voltage $\left(V_{M P P}\right)$ maximum power $(M P P)$, fill factor $(F F)$ and efficiency $(\eta)$ are included. The table presents results of measurements that were conducted onto freshly made DSSC and after 72-hour ageing process.

The maximum efficiency of $4-5 \%$ can be achieved when the proper amount of the dye is adsorbed on $\mathrm{TiO}_{2}$ electrode which means that the combination of dye concentration and time of soaking the electrode in dye solution is optimal.
The results show that dipping in dye solution of low concentration (e.g. $0.25 \mathrm{mM}$ ) requires longer time of electrode immersion in the solution (e.g. 24 h). The set of samples no. 3 achieved the highest working parameters from $0.25 \mathrm{mM}$-group of the tested cells. The 24-hour immersion allowed to obtain $142 \%$ higher $\boldsymbol{J}_{s c}$ value compared to sample no. 1 and $10 \%$ improvement compared to sample no. 2 . The same trend is visible in $\eta$ value. The opposite relation also works, thus higher dye concentration needs to be accompanied by shorter dipping time. This can be shown on the basis of the set of samples no. 5 and 7 . The best performance obtained the sample immersed by 2 hours (sample no. 5) which results in $20 \%$ improvement in efficiency (from $\sim 3.8 \%$ to $4.55 \%$ ). Sample no. 7 is a representative of the samples from group of $1 \mathrm{mM}$ dye concentration and it obtained $25 \%$ and $19 \%$ higher efficiency value that the other two sets.

The best efficiency values are achieved for the following combinations of concentration and time: $0.25 \mathrm{mM}$ and $24 \mathrm{~h}, 0.5 \mathrm{mM}$ and $2 \mathrm{~h}, 1 \mathrm{mM}$, and $1 \mathrm{~h}$ (Table 2 ). The experimental results also indicate that the higher dye concentrations $(0.5 \mathrm{mM}$ and $1 \mathrm{mM})$ are preferable. Measurements performed $72 \mathrm{~h}$ after the preparation of the cells provide better results than performed right after the assembly of the cells. This observation can be

Table 2. Characteristic parameters of dye-sensitized solar cells differing by dye concentration and time of dipping in the N719 dye solution. Ageing was evaluated by comparison of the measurements performed right after cell preparation - row A, and later, after $72 \mathrm{~h}$ - row B in the third column.

\begin{tabular}{|c|c|c|c|c|c|c|c|c|c|c|c|}
\hline Dye concentration & $\mathrm{Ne}$ & Dipping time & Aring & $\mathrm{J}_{\mathrm{sc}}$ & $\mathrm{I}_{\mathrm{sc}}$ & $\mathrm{V}_{\mathrm{oc}}$ & $\mathrm{I}_{\mathrm{MPP}}$ & $\mathrm{V}_{\mathrm{MPP}}$ & $\mathrm{P}_{\mathrm{MPP}}$ & $\mathrm{FF}$ & $\eta$ \\
\hline [mM] & No. & [h] & Ageming & {$\left[\mathrm{mA} / \mathrm{cm}^{2}\right]$} & {$[\mathrm{mA}]$} & {$[\mathrm{mV}]$} & {$[\mathrm{mA}]$} & {$[\mathrm{mV}]$} & {$[\mathrm{mW}]$} & [\%] & {$[\%]$} \\
\hline \multirow{6}{*}{0.25} & \multirow{2}{*}{1} & \multirow{2}{*}{$1 \mathrm{~h}$} & $A$ & 4.43 & 3.54 & 636.58 & 2.76 & 441.50 & 1.22 & 54.02 & 1.52 \\
\hline & & & B & 1.67 & 1.34 & 588.71 & 1.06 & 371.00 & 0.39 & 50.07 & 0.49 \\
\hline & \multirow{2}{*}{2} & \multirow{2}{*}{$2 \mathrm{~h}$} & $A$ & 9.77 & 6.84 & 688.64 & 5.06 & 469.71 & 2.38 & 50.47 & 2.97 \\
\hline & & & $B$ & 9.85 & 6.89 & 701.87 & 5.13 & 474.41 & 2.43 & 50.29 & 3.48 \\
\hline & \multirow{2}{*}{3} & \multirow{2}{*}{$24 \mathrm{~h}$} & A & 10.74 & 8.59 & 693.07 & 6.72 & 469.72 & 3.16 & 52.97 & 3.94 \\
\hline & & & B & 11.49 & 9.19 & 712.54 & 7.29 & 474.40 & 3.46 & 52.85 & 4.33 \\
\hline \multirow{6}{*}{0.50} & \multirow{2}{*}{4} & \multirow{2}{*}{$1 \mathrm{~h}$} & A & 9.77 & 7.81 & 708.43 & 6.26 & 488.54 & 3.06 & 55.22 & 3.82 \\
\hline & & & B & 9.47 & 7.58 & 725.82 & 5.60 & 507.36 & 3.03 & 55.21 & 3.79 \\
\hline & \multirow{2}{*}{5} & \multirow{2}{*}{$2 \mathrm{~h}$} & A & 12.21 & 9.77 & 708.50 & 7.82 & 465.00 & 3.64 & 52.58 & 4.55 \\
\hline & & & $B$ & 12.47 & 9.97 & 723.98 & 8.10 & 479.11 & 3.88 & 53.78 & 4.85 \\
\hline & \multirow{2}{*}{6} & \multirow{2}{*}{$24 \mathrm{~h}$} & $A$ & 10.52 & 8.42 & 695.19 & 6.64 & 455.58 & 3.03 & 51.71 & 3.78 \\
\hline & & & $B$ & 10.87 & 8.70 & 700.84 & 6.89 & 469.70 & 3.24 & 53.09 & 4.04 \\
\hline \multirow{6}{*}{1.00} & \multirow{2}{*}{7} & \multirow{2}{*}{$1 \mathrm{~h}$} & A & 12.34 & 9.87 & 691.40 & 7.37 & 455.59 & 3.36 & 49.15 & 4.19 \\
\hline & & & $B$ & 12.29 & 9.84 & 713.31 & 7.49 & 469.70 & 3.52 & 50.15 & 5.03 \\
\hline & \multirow{2}{*}{8} & \multirow{2}{*}{$2 \mathrm{~h}$} & A & 11.17 & 8.94 & 684.72 & 5.99 & 422.65 & 2.53 & 41.39 & 3.17 \\
\hline & & & $B$ & 12.84 & 10.28 & 711.59 & 7.09 & 422.65 & 3.00 & 41.01 & 4.28 \\
\hline & \multirow{2}{*}{9} & \multirow{2}{*}{$24 \mathrm{~h}$} & $A$ & 9.75 & 7.80 & 679.15 & 6.00 & 455.59 & 2.74 & 51.66 & 3.42 \\
\hline & & & B & 10.52 & 8.41 & 698.46 & 6.66 & 469.69 & 3.13 & 53.23 & 3.91 \\
\hline
\end{tabular}


explained with penetration of electrolyte which requires some time to fill the mesoporous structure of $\mathrm{TiO}_{2}$ layer. It is interesting to notice that the improvement in working parameters is legible and it is found that ageing effect shows a positive influence on working parameters. Even 20\% improvement of parameters can be observed after 72 hours (e.g. efficiency of sample no. 7 changed from $4.19 \%$ to $5.03 \%$ ). The loss of performance occurring after 72 hours in sample no. 1 can be explained by progressive loss of electrolyte that resulted in improper operation of the cell.

\section{CONCLUSIONS}

Dye cells sensitized with N719 dye were prepared and sealed according to the procedure that assure their the proper operation. The vast majority of the cells were stable during the measurements and no leakage of the electrolyte was observed for minimum a few days. The results show that the increase of dye solution concentration has to be accompanied by the decrease of dipping time of the $\mathrm{TiO}_{2}$ electrode in order to achieve the finest performance parameters. The cell prepared with the electrode immersed for $1 \mathrm{~h}$ in $1 \mathrm{mM}$ dye solution exhibited the highest efficiency of 5\% after ageing for $72 \mathrm{~h}$. The beneficial influence of ageing was observed in the presented results which suggest that liquid electrolyte needs some time to penetrate the pores in $\mathrm{TiO}_{2}$ structure and create the interface enabling electrons to transfer in order to regenerate the dye.

\section{Acknowledgements}

This work was supported by Polish Ministry of Science and Higher Education.

\section{REFERENCES}

1. bp-stats-review-2019-full-report.pdf. 2019. 68th edition. (accessed on Apr 20, 2020).

2. Chowdhury F. I., Buraidah M. H., Arof A. K., Mellander B.-E., Noor I. M. 2020. Impact of tetrabutylammonium, iodide and triiodide ions conductivity in polyacrylonitrile based electrolyte on DSSC performance. Solar Energy, 196, 379-88.

3. Galliano S., Bella F., Piana G., Giacona G., Viscardi G., Gerbaldi C., Grätzel M., Barolo C. 2018. Finely tuning electrolytes and photoanodes in aqueous solar cells by experimental design. Solar Energy, 163, 251-55.
4. Gong J., Sumathy K., Qiao Q., Zhou Z. 2017. Review on dye-sensitized solar cells (DSSCs): Advanced techniques and research trends. Renewable and Sustainable Energy Reviews, 68, 234-46.

5. Gong L., Liu Y., Gu X., Lu J., Zhang J., Ye Z., Chen Z., Li L. 2014. Study on the thermal stability of Gadoped $\mathrm{ZnO}$ thin film: A transparent conductive layer for dye-sensitized $\mathrm{TiO} 2$ nanoparticles based solar cells. Materials Science in Semiconductor Processing, 26, 276-81.

6. Grätzel M. 2005. Solar Energy Conversion by DyeSensitized Photovoltaic Cells. Inorganic Chemistry, 44(20), 6841-51.

7. Gulkowski S., Zdyb A., Dragan P. 2019. Experimental Efficiency Analysis of a Photovoltaic System with Different Module Technologies under Temperate Climate Conditions. Applied Sciences, 9(141), 1-13.

8. Höök M., Tang X. 2013. Depletion of fossil fuels and anthropogenic climate change-A review. Special Section: Transition Pathways to a Low Carbon Economy, 52, 797-809.

9. Hossain M. K., Mortuza A. A., Sen S. K., Basher M. K., Ashraf M. W., Tayyaba S., Mia M. N. H., Uddin M. J. 2018. A comparative study on the influence of pure anatase and Degussa-P25 TiO2 nanomaterials on the structural and optical properties of dye sensitized solar cell (DSSC) photoanode. Optik, 171, 507-16.

10. Ito S., Chen P., Comte P., Nazeeruddin M. K., Liska P., Péchy P., Grätzel M. 2007. Fabrication of screenprinting pastes from $\mathrm{TiO} 2$ powders for dye-sensitised solar cells. Progress in Photovoltaics: Research and Applications, 15(7), 603-12.

11. Kabir F., Sakib S. N., Matin N. 2019. Stability study of natural green dye based DSSC. Optik, 181, 458-64.

12. Karim N. A., Mehmood U., Zahid H. F., Asif T. 2019. Nanostructured photoanode and counter electrode materials for efficient Dye-Sensitized Solar Cells (DSSCs). Solar Energy, 185, 165-88.

13. Krawczak E., Zdyb A. 2019. The influence of the dye adsorption time on the DSSC performance. Edited by B. Kaźmierczak, P. Jadwiszczak, M. Kutyłowska, and U. Miller. E3S Web of Conferences, 100, 00040.

14. Krawczyk S., Nawrocka A., Zdyb A. 2018. Chargetransfer excited state in pyrene-1-carboxylic acids adsorbed on titanium dioxide nanoparticles. Spectrochimica Acta Part A: Molecular and Biomolecular Spectroscopy, 198, 19-26.

15. Kundu S., Sarojinijeeva P., Karthick R., Anantharaj G., Saritha G., Bera R., Anandan S., et al. 2017. Enhancing the Efficiency of DSSCs by the Modification of TiO2 Photoanodes using N, F and S, codoped Graphene Quantum Dots. Electrochimica 
Acta, 242, 337-43.

16. Kurz D., Nawrowski R. 2017. Analysis of the impact of thermal resistance of the roof on the performance of photovoltaic roof tiles. E3S Web of Conferences, 19, 01039.

17. Louwen A., Sark W. G. J. H. M. van, Faaij A. P. C., Schropp R. E. I. 2016. Re-assessment of net energy production and greenhouse gas emissions avoidance after 40 years of photovoltaics development. Nature Communications, 7(1), 13728.

18. Nazeeruddin Md. K., Baranoff E., Grätzel M. 2011. Dye-sensitized solar cells: A brief overview. Solar Energy, 85(6), 1172-78.

19. Önen T., Karakuş M. Ö., Coşkun R., Çetin H. 2019. Reaching stability at DSSCs with new type gel electrolytes. Journal of Photochemistry and Photobiology A: Chemistry, 385, 112082.

20. O’Regan B., Grätzel M. 1991. A low-cost, high-efficiency solar cell based on dye-sensitized colloidal TiO 2 films. Nature, 353(6346), 737-40.

21. Parthiban R., Balamurugan D., Jeyaprakash B. G. 2015. Spray deposited $\mathrm{ZnO}$ and $\mathrm{Ga}$ doped $\mathrm{ZnO}$ based DSSC with bromophenol blue dye as sensitizer: Efficiency analysis through DFT approach. Materials Science in Semiconductor Processing, 31, 471-77.

22. Peng T., Xu J. 2020. Composite electrode of $\mathrm{TiO} 2$ particles with three kinds of crystal phases for significantly improved performance of dye-sensitized solar cells. Chemical Physics, 533, 110744.

23. Photovoltaic Research. https://www.nrel.gov (accessed on Apr 21, 2020).

24. Quintana M., Edvinsson T., Hagfeldt A., Boschloo G. 2007. Comparison of Dye-Sensitized $\mathrm{ZnO}$ and TiO2 Solar Cells: Studies of Charge Transport and Carrier Lifetime. The Journal of Physical Chemistry C, 111(2), 1035-41.

25. Rahman M. U., Xie F., Li Y., Sun X., Wei M. 2019. Grafting cobalt sulfide on graphene nanosheets as a counterelectrode for dye-sensitized solar cells. Journal of Alloys and Compounds, 808, 151701.

26. Shikoh A. S., Ahmad Z., Touati F., Shakoor R. A., Al-Muhtaseb S. A. 2017. Optimization of ITO glass/ TiO2 based DSSC photo-anodes through electrophoretic deposition and sintering techniques. Ceramics International, 43(13), 10540-45.

27. Singh L. K., Koiry B. P. 2018. Natural Dyes and their Effect on Efficiency of TiO2 based DSSCs: a Comparative Study. Materials Today: Proceedings, 5(1, Part 2), 2112-22.
28. Subalakshmi K., Senthilselvan J. 2018. Effect of fluorine-doped $\mathrm{TiO} 2$ photoanode on electron transport, recombination dynamics and improved DSSC efficiency. Solar Energy, 171, 914-28.

29. Teuscher J., Marchioro A., Andrès J., Roch L. M., Xu M., Zakeeruddin S. M., Wang P., Grätzel M., Moser J.-E. 2014. Kinetics of the Regeneration by Iodide of Dye Sensitizers Adsorbed on Mesoporous Titania. The Journal of Physical Chemistry C, 118(30), 17108-15.

30. Ueno N., Dwijaya B., Uchida Y., Egashira Y., Nishiyama N. 2013. Synthesis of mesoporous $\mathrm{ZnO}, \mathrm{AZO}$, and BZO transparent conducting films using nonionic triblock copolymer as template. Materials Letters, 100, 111-14.

31. Unal F. A., Ok S., Unal M., Topal S., Cellat K., Şen F. 2020. Synthesis, characterization, and application of transition metals ( $\mathrm{Ni}, \mathrm{Zr}$, and $\mathrm{Fe}$ ) doped $\mathrm{TiO} 2$ photoelectrodes for dye-sensitized solar cells. Journal of Molecular Liquids, 299, 112177.

32. Wajs J., Golabek A., Bochniak R., Mikielewicz D. 2020. Air-cooled photovoltaic roof tile as an example of the BIPVT system - An experimental study on the energy and exergy performance. Energy, 197, 117255 .

33. Zalas M., Jelak K. 2020. Optimization of platinum precursor concentration for new, fast and simple fabrication method of counter electrode for DSSC application. Optik, 206, 164314.

34.Zdyb A., Krawczak E., Gułkowski S. 2018. The influence of annealing on the properties of $\mathrm{ZnO}: \mathrm{Al}$ layers obtained by RF magnetron sputtering. OptoElectronics Review, 26(3), 247-51.

35. Zdyb A., Krawczak E., Lichograj P. 2016. Characterization of $\mathrm{ZnO}: \mathrm{Al}$ layers for applications in thin film solar cells. Optica Applicata, 46(2), 181-85.

36. Zdyb A., Krawczyk S. 2016. Characterization of adsorption and electronic excited states of quercetin on titanium dioxide nanoparticles. Spectrochimica Acta Part A: Molecular and Biomolecular Spectroscopy, 157, 197-203.

37. Zhang L., Huang J., Yang J., Tang K., Ren B., Hu Y., Wang L., Wang L. 2016. The effects of thickness on properties of $\mathrm{B}$ and $\mathrm{Ga}$ co-doped $\mathrm{ZnO}$ films grown by magnetron sputtering. Materials Science in Semiconductor Processing, 42, 277-82.

38. Zidane T. E. K., Adzman M. R. B., Tajuddin M. F. N., Zali S. M., Durusu A. 2019. Optimal configuration of photovoltaic power plant using grey wolf optimizer: A comparative analysis considering $\mathrm{CdTe}$ and c-Si PV modules. Solar Energy, 188, 247-57. 